\title{
Responsabilidade Social universitária: um estudo sobre seu significado para os representantes dos grupos de interesse de uma universidade
}

\author{
Carla de Cássia Nardelli Vieira모 Sheila Patrícia Ramos Beckhauser ${ }^{2}$, Iara Regina \\ dos Santos Parisotto 3 \\ ${ }^{1}$ Universidade Regional de Blumenau (FURB) - carladecnvieira@gmail.com \\ ${ }^{2}$ Universidade Regional de Blumenau (FURB) - spr8osc@gmail.com \\ 3 Universidade Regional de Blumenau (FURB) - iaraparisotto@furb.br
}

\section{PALAVRAS-CHAVE}

Responsabilidade social universitária;

Impactos universitários;

Teoria dos stakeholders.

Recebido 07.08.2018

Revisado 13.03.2019

Aceito 03.04.2019

ISSN 1980-4431

Double blind review

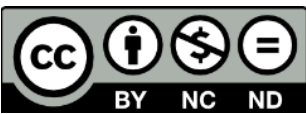

\section{RESUMO}

Este estudo tem como objetivo analisar como os representantes dos grupos de interesse compreendem a responsabilidade social universitária da Fundação Universidade Regional de Blumenau. Para atingir este objetivo optou-se por estudo exploratório, qualitativo e estudo de caso. A coleta de dados foi realizada por meio de entrevista com 23 membros do Conselho Universitário e documentos. Para a análise e interpretação dos dados coletados foram utilizadas a análise de conteúdo e a análise documental. Como resultados este estudo apontou a dificuldade de institucionalizar ações de responsabilidade social universitária, as quais são realizadas, mas estão fragmentadas e desarticuladas de forma a não propiciar condições para a indissociabilidade do ensino, da pesquisa e da extensão. Este aspecto reflete no relacionamento com os stakeholders, que muitas vezes não encontram os canais para especificar suas demandas, bem como conhecer o que é feito pela Instituição. Esta fragilidade pode estar influenciando na percepção da imagem da Instituição por seus stakeholders, que a julgam como reativa e fechada.

\section{KEYWORDS}

University social responsibility; University Impacts;

Stakeholder theory.

\section{ABSTRACT}

This study aims to analyze how representatives of interest groups understand the university social responsibility of the Blumenau Regional University Foundation. To reach this goal we opted for exploratory, qualitative study and case study. Data collection was done through an interview with 23 members of the University Council and documents. For the analysis and interpretation of the data collected, content analysis and document analysis were used. As results, this study pointed to the difficulty of institutionalizing university social responsibility actions, which are carried out, but are fragmented and disarticulated so as not to provide conditions for the indissociability of teaching, research and extension. This aspect reflects in the relationship with the stakeholders, who often do not find the channels to specify their demands, as well as to know what is done by the Institution. This fragility may be influencing the perception of the Institution's image by its stakeholders, who consider it as reactive and closed. 


\section{Introdução}

Responsabilidade social é tema discutido em diversos setores da sociedade, inclusive pelas Instituições de ensino superior (IES). No âmbito da educação superior, a partir de 2004, por meio da Lei 10.861, de 14 de abril de 2004, o Sistema Nacional de Avaliação do Ensino Superior (SINAES) tem sido o norteador dos instrumentos de avaliação das IES públicas e privadas, no qual há dimensão que trata especificamente da responsabilidade social. A contribuição das IES se observa por meio de: inclusão social, o desenvolvimento econômico e social, a defesa do meio ambiente, da memória cultural, da produção artística e do patrimônio cultural (INEP, 2004; Furlani, 2005). Para Jugón \& Corral (2012), quando se pensa em responsabilidade social universitária (RSU) se pensa em compromisso com gestão responsável e em assumir os efeitos internos e externos que geram a universidade. Além dos aspectos sinalizados pelo SINAES, Vallaeys, Cruz \& Sasia (2009) argumentam que a RSU acontece por meio dos impactos das atividades de ensino, pesquisa, extensão e gestão, sendo os impactos positivos evidenciados e reportados aos grupos de interesse e sociedade, e os negativos corrigidos. Para González (2012), a proposta de gerir a responsabilidade parte do diálogo com todos os grupos da organização, buscando averiguar interesses e valores comuns.

A universidade faz parte da sociedade e com ela estabelece interação dinâmica, e assim tem como função prover os membros da comunidade de conhecimentos, envolvendo os diferentes atores da sociedade. A responsabilidade social se desenvolve quando a organização toma consciência de si mesma, de seu entorno e do papel que representa (Vallaeys, 2006; Villarreal, 2014). Este envolvimento requer uma relação construtiva entre organização e seus grupos de interesse, pois compreender as expectativas da sociedade se tornou essencial, no qual a comunicação estabelece o elo entre seus elementos (Marchiori, 2010; Junqueira \& Wada, 2011). Desta forma, a finalização do processo de RSU perpassa pela prestação de contas das ações desenvolvidas aos stakeholders da organização, ao fornecer subsídios para sua tomada de decisão, para a autoaprendizagem institucional e para a consolidação do compromisso com a responsabilidade social, não sendo um mero recurso informativo para a universidade (Vallaeys, Cruz \& Sasia, 2009).

Assim, o estudo do tema da presente pesquisa possui relevância já que é fator determinante na avaliação institucional realizada pelo Ministério da Educação (MEC), representando 5\% da nota final. E ainda, a responsabilidade social é um tema norteador do instrumento de avaliação do SINAES, órgão competente que avalia as instituições de ensino superior, pública e privada no Brasil.

Considerando que responsabilidade social universitária decorre do entendimento do próprio conceito, das ações adotadas pela universidade e do relacionamento com a comunidade acadêmica, surge a seguinte indagação: qual o significado de responsabilidade social universitária para os representantes dos grupos de interesse da FURB?

Como contribuição teórica, o estudo buscou compreender o significado da RSU, visto que é considerado um tema abrangente e complexo, por meio das ações realizadas na universidade, na percepção de seus stakeholders. Além disso, o estudo procurou identificar os impactos decorrentes dos modelos de gestão universitaria sobre a RSU.

\section{Referencial Teórico}

Nesta seção, inicia-se pelo conceito de responsabilidade social universitária seguindo com a explanação sobre a função social da universidade e sobre SINAES, no qual a responsabilidade social faz parte como critério para a avaliação das IES. Apresentam-se também os impactos universitários, sendo o eixo horizontal ou acadêmico (ensino e pesquisa) específico da atuação das universidades e o eixo vertical ou organizacional (gestão e extensão) comum às organizações em geral, conforme Vallaeys, Cruz \& Sasia (2009). Por fim, apresenta-se o referencial teórico sobre a teoria dos stakeholders e como se estabelece a relação e a comunicação das organizações com os seus grupos de interesse.

\subsection{Responsabilidade Social Universitária}

Responsabilidade social é uma área de interesse inter e multidisciplinar, que perpassa por vários campos das ciências sociais e humanas (Oliveira, 2008). O termo responsabilidade pode ter diferentes interpretações. Como um substantivo derivado do verbo responder, significa produzir

Revista de Negócios, v. 23, n. 4, p. 7-24, October, 2018. 
efeito, satisfazer, justificar, pagar, comprometer-se e prometer. Desmembrando esta mesma palavra, o prefixo latino re indica movimento reverso, retorno, reforço, intensificação de uma ação, enquanto os radicais spondi e dere significam esperança, expectativa, promessa ou garantia.

Em termos gerais, a responsabilidade de um agente se refere à obrigação de responder pelas consequências previsíveis de suas ações em virtude de leis, contratos, normas de grupos sociais ou de sua convicção íntima, sendo a capacidade de escolha das ações uma condição básica para o surgimento da responsabilidade desses agentes (Barbieri \& Cajazeira, 2009). Segundo Dias (2012), responsabilidade social é um conjunto de ideias e práticas da organização que fazem parte de sua estratégia e que tem como objetivo evitar prejuízos e/ou gerar benefícios para todas as partes interessadas, adotando-se métodos racionais para atingir esses fins e que devem resultar em benefícios para a organização e para a sociedade.

Cruvinel (2008) alega a falta de consenso sobre o conceito de responsabilidade social e seus limites e, desta forma, configura-se como objeto de disputa. Álvarez \& Liarti (2012) relatam que a responsabilidade social é uma expressão que tomou força nos últimos anos na agenda econômica e empresarial e, posteriormente, política e social, porém existe vários termos a ela associados sem alcançar um conceito único, o que repercute no momento de estabelecer estratégias e direções.

Para Melo Neto \& Froes (2001) a maior dificuldade para definir responsabilidade social está na amplitude do tema e, assim, na extensão do seu espectro. A responsabilidade social empresarial (RSE) é considerada uma conduta que vai da ética nos negócios às ações desenvolvidas na comunidade, passando pelo tratamento dos funcionários e relações com acionistas, fornecedores e clientes. Da amplitude do tema reflete na complexidade do conceito, compreendendo valores, ações e relações.

Quando tratada na educação superior, a literatura traz os termos RSU e RSES. Para Calderón (2005), quando se discute o papel social ou a função social da educação superior brasileira, o termo historicamente cunhado é compromisso social. Segundo Calderón, Pedro \& Vargas (2011), o termo RSES surgiu no Brasil com o processo de institucionalização do mercado de Educação Superior, no início da primeira década do século $\mathrm{XXI}$, quando IES privadas o incorporaram como estratégia de marketing, semelhante às empresas. Foi a partir de 2004, com a instituição do SINAES, que esta questão foi formalmente incorporada no cenário brasileiro.

Segundo Martino (2012), responsabilidade social deve ser parte essencial da missão de toda universidade, que aplicada a tal instituição permite reformular o seu compromisso social para maior pertinência e integração de suas funções. $O$ compromisso social das IES e a defesa de ideais humanísticos, considerados históricos na construção da sociedade justa e democrática, são pontos convergentes no debate em relação ao seu papel no âmbito da responsabilidade social, como também oferecem oportunidade para a inovação e a elaboração de respostas críticas e criativas advindas do confronto com a própria realidade e das diferentes compreensões que provocam (Maciel, Kowalski \& Menezes, 2009).

Para Rosetto \& Brito (2013), o conceito de responsabilidade social estabelecido pelo SINAES é abrangente, porém, passados vários anos de sua criação, traz um entendimento limitado, arraigado ao contexto empresarial. Desta forma, por não conseguir identificar nas bases pesquisadas, os referenciais utilizados pelo MEC para definir os elementos constantes no conceito do SINAES sobre responsabilidade social, buscou-se, em outros campos teóricos, fundamentos para compreender o que se pode alcançar quanto à contribuição em relação a: a inclusão social, o desenvolvimento econômico e social, a defesa do meio ambiente, da memória cultural, da produção artística e do patrimônio cultural.

Para Gugel (2004), a inclusão social, entendida como um processo abrangente de preparação de todos para receber, acolher e conviver com a diversidade, só é possível se cumpridos os direitos sociais constantes no art. $6^{\circ}$ da Constituição Federal: educação, saúde, alimentação, trabalho, moradia, lazer, segurança, previdência social, proteção à maternidade e à infância e assistência aos desamparados. A diversidade, por sua vez, refere-se às diferenças sociais, culturais, étnicas, políticas, religiosas, educacionais, de gênero, sexual, ambiental e científica.

Felicetti (2011) traz que a inclusão não é entendida como um problema somente da pessoa interessada, mas do sistema no qual ela deve ser inserida. Desta forma, inclusão social voltada para a educação, diz respeito à um conjunto de ações

Revista de Negócios, v. 23, n. 4, p. 7-24, October, 2018. 
que combatem a exclusão dos benefícios da educação em sociedade (sociedade esta, que estabelece padrões igualitários, contradizendo o perfil populacional delineado por diferenças). Schwartzman (2005) relata a importância da ampliação da presença de pessoas em condições plurais e diferenciadas nas IES. Santos (2004) propõe a inclusão quanto ao acesso à educação superior, por meio de políticas de ação afirmativa para corrigir uma exclusão histórica de acesso. Programas de acesso ao ensino superior, segundo Aprile \& Barone (2009), inserem-se no âmbito de políticas inclusivas compensatórias, que visam corrigir lacunas deixadas pelas insuficiências das políticas universalistas.

Propostas como a concessão de bolsas de estudos, vagas por critérios raciais ou socioeconômicos e financiamento estudantil representam um esforço meritório de distribuição e de seleção para o acesso à educação superior, no sentido de combater o tradicional elitismo social da universidade brasileira (Santos, 2004; Aprile \& Barone, 2009). Porém estas ações têm provocado debates e resistências em sua implementação, incidindo na contraposição entre democratização do acesso e meritocracia, como também em temas como o método de reserva de vagas e as dificuldades em aplicar critério racial numa sociedade altamente miscigenada.

Quando se aborda o tema desenvolvimento econômico e social e defesa do meio ambiente, a literatura sobre responsabilidade social remete ao conceito de triple botton line (TBL), ou tripé da sustentabilidade, de Elkington (1997). Elkington publicou o livro Cannibals with forks (Canibais com garfo e faca), e utiliza esta metáfora para comparar o capitalismo a um canibal, questionando se este se tornaria civilizado se usasse garfo. Os dentes do garfo para o capitalismo se referem às dimensões econômica, social e ambiental da sustentabilidade. Este modelo ganhou popularidade e sua aplicação destina-se às empresas, entidades públicas, cooperativas e outras organizações da sociedade civil sem fins lucrativos (Barbieri \& Cajazeira, 2009).

Para Mascarenhas \& Silva (2013), os componentes fundamentais para o desenvolvimento sustentável são: crescimento econômico, proteção ao meio ambiente e igualdade social. Conforme Barbieri \& Cajazeira (2009), a dimensão econômica possibilita a alocação e gestão eficiente dos recursos produtivos, bem como um fluxo regular de investimentos públicos e privados. A dimensão social trata da consolidação de processos que promovem a equidade na distribuição de bens e de renda para melhorar os direitos e condições da população e reduzir a distância entre os padrões de vida das pessoas. A dimensão ambiental ou ecológica se refere às ações para aumentar a capacidade de carga do planeta e evitar danos ao meio ambiente causados pelos processos de desenvolvimento.

\subsection{Impactos Universitários}

As universidades, por desempenharem atividades de ensino, pesquisa e extensão se diferenciam dos demais tipos de organização e são consideradas complexas pela imposição dos métodos de trabalho diferentes, pela natureza dos trabalhos, pelas tecnologias utilizadas, pelas pessoas que nela trabalham e por seus clientes (Silva, 1991). Meyer Jr. (2007) e Pereira et al. (2008) destacam as principais características das IES: a) metas difusas e ambíguas; b) clientes com necessidades distintas e complexas, o que gera problemas de tecnologia; c) predominância de pessoal especializado; d) vulnerabilidade ao ambiente externo; e) natureza intangível de seus produtos; f) processo decisório; g) dificuldade de avaliar o valor agregado; $h$ ) interesses organizacionais sobrepujados pelos interesses profissionais individuais; e i) administração universitária.

A Declaração Mundial sobre Educação Superior, desenvolvida pela Organização das Nações Unidas para a Educação, a Ciência e a Cultura (UNESCO) descreve as funções e as missões que devem ser implantadas pelas IES, em seu artigo primeiro: a missão de educar, formar e realizar pesquisas, no qual as missões e valores fundamentais da educação superior, em particular a missão de contribuir para o desenvolvimento sustentável e o melhoramento da sociedade como um todo, devem ser preservados, reforçados e expandidos (UNESCO, 1998).

Quanto à função aborda-se a ética, a autonomia, a responsabilidade e a função preventiva, na qual IES, pessoal e estudantes devem: a) preservar e desenvolver suas funções fundamentais; b) poder opinar em problemas éticos, culturais e sociais de forma completamente independente e com consciência plena de suas responsabilidades; c) ampliar suas funções críticas

Revista de Negócios, v. 23, n. 4, p. 7-24, October, 2018. 
e prospectivas; d) utilizar sua capacidade intelectual e prestígio moral para defender $\mathrm{e}$ difundir ativamente os valores aceitos universalmente, particularmente a paz, a justiça, a liberdade, a igualdade e a solidariedade, tal como consagrados na Constituição da UNESCO; e) desfrutar de liberdade acadêmica e autonomia plenas; e f) desempenhar seu papel na identificação e tratamento dos problemas que afetam o bem-estar das comunidades, nações e da sociedade global (UNESCO, 1998).

No tocante a questões que envolvem a universidade socialmente responsável, órgãos internacionais se empenham na discussão de assuntos referentes ao ensino superior, considerando a RSU como a capacidade que tem a universidade em colocar em prática um conjunto de princípios e valores, por meio de seus principais processos (gestão, ensino, pesquisa e extensão) (Jimenez, Fontecilla \& Troncoso, 2006; Pinto, 2012).

Vallaeys, Cruz \& Sasia (2009) argumentam que o caminho mais prático para definir RSU é considerar os impactos que a instituição gera em seu entorno, os quais podem ser agrupados em quatro categorias: organizacional, educativo, cognitivo e social. De acordo com este esquema, o eixo vertical é comum às organizações em geral, pois todas geram impactos laborais, ambientais e sociais; o eixo horizontal, designado como eixo acadêmico, é desempenhado especificamente pelas instituições de aprendizagem e conhecimento (que no Brasil correspondem às universidades), conforme Figura 1:

Figura 1 - Eixos dos impactos universitários.

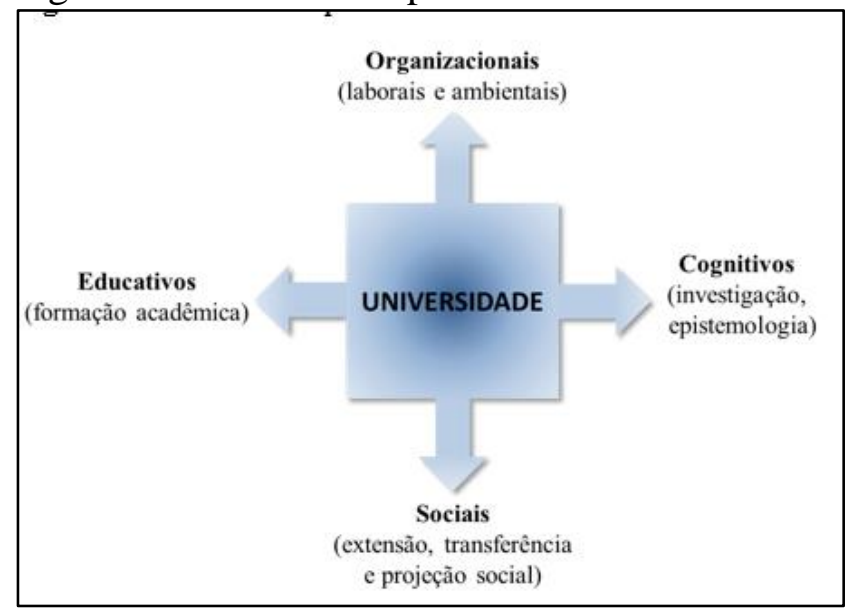

Fonte: Vallaeys, Cruz \& Sasia (2009).

Os impactos gerados pelas universidades podem ser positivos ou negativos, conforme exposto na Figura 2:

Figura 2 - Possíveis impactos gerados pelas universidades.

\begin{tabular}{|c|c|c|}
\hline Atividade & Impactos positivos & Impactos negativos \\
\hline Ensino & $\begin{array}{l}\text { - Formação cidadã e profissional responsável } \\
\text { - Aprendizagem socialmente pertinente e solidária } \\
\text { - Matrizes curriculares socialmente consensuadas }\end{array}$ & $\begin{array}{l}\text { - Hiperespecialização } \\
\text { - Falta de formação ética e cidadã } \\
\text { - Reducão da formação à empregabilidade }\end{array}$ \\
\hline Pesquisa & $\begin{array}{l}\text { - Promoção da inter e da transdisciplinaridade } \\
\text { - Pertinência social da investigação } \\
\text { - Responsabilidade social da ciência }\end{array}$ & $\begin{array}{l}\text { - Desvinculação academia e sociedade } \\
\text { - Irresponsabilidade cientifica } \\
\text { - Fragmentação do saber } \\
\text { - Carência de transdisciplinaridade }\end{array}$ \\
\hline Extensão & $\begin{array}{l}\text { - Participação social } \\
\text { - Aprendizagem mútua e permanente para o } \\
\text { desenvolvimento social } \\
\text { - Contribuição na solução de problemas sociais } \\
\text { concretos }\end{array}$ & $\begin{array}{l}\text { - Assitencialismo/paternalismo } \\
\text { - Mercantilização da extensão } \\
\text { - Indiferença aos problemas sociais }\end{array}$ \\
\hline Gestão & $\begin{array}{l}\text { - Sistema de gestão ético e transparente } \\
\text { - Boas práticas laborais } \\
\text { - Boas práticas ambientais }\end{array}$ & $\begin{array}{l}\text { - Incongruências éticas institucionais } \\
\text { - Maltrato laboral } \\
\text { - Falta de democracia e transparência } \\
\text { - Maus hábitos ambientais }\end{array}$ \\
\hline
\end{tabular}

Fonte: Adaptado de Vallaeys (2008) e Vallaeys, Cruz \& Sasia (2009)

Este modelo dissipa a confusão entre RSU e RSE e oferece outras vantagens como (Vallaeys, 2014):

a) Evolução do conceito de responsabilidade social, por não ser mera aplicação das normas vigentes às universidades, pois incide sobre as atividades de competência acadêmica;

b) Este enfoque é mais amplo que o norteamericano e europeu, cujo foco está voltado para a dimensão ambiental (conceito de campus sustentável), com pouco enfoque nos processos formativos, cognitivos e epistemológicos;

c) Desenvolve crítica contra o paradigma de expansão latino-americana, que tende a reduzir a RSU em mero compromisso de solidariedade com populações carentes, e desvela os problemas internos da universidade que são visíveis fora dela;

d) Constitui uma arma para enfrentar a nova tendência de mercantilização digital, que por um lado é entendida como democratização do conhecimento, mas por outro é considerada como mercantilização feroz e desenraizamento da educação, devido à padronização do conhecimento para qualquer pessoa e em qualquer lugar.

O ensino constitui o campo de atividade com maior visibilidade social da universidade (Morais, Almeida \& Montenegro, 2006). O ensino é considerado socialmente responsável, quando se tem como princípio ético do ensino superior e da responsabilidade social, proporcionar uma educação voltada para o desenvolvimento humano, sendo este um processo que visa ampliar as possibilidades oferecidas às pessoas, sendo as principais: vida longa e com saúde; adquirir conhecimentos; e ter acesso aos recursos necessários à um nível de vida decente (Calderón,

Revista de Negócios, v. 23, n. 4, p. 7-24, October, 2018. 
2005; Medeiros Jr., 2004). De acordo com Rösler \& Ortigara (2005), a adequação da oferta de educação, que incorpore a reflexão sobre valores sociais e a preparação para o trabalho, englobará o aprender a: ser, fazer, aprender e empreender.

A pesquisa é considerada socialmente responsável, não como um compromisso para o futuro, mas como uma obrigação para o presente. O ensino e a pesquisa trabalhados na dimensão da ciência terão o compromisso com a realidade e com o trabalho extramuros, alargando as relações e os compromissos das IES com seu entorno (Calderón, 2005; Medeiros Jr., 2004). Herrera (2012) relata que a ciência e a tecnologia, a formação universitária e a pesquisa devem contribuir a recuperar o sujeito como indivíduo capaz de situarse frente a sua realidade, de pensá-la de novas maneiras e de transformá-la.

A extensão universitária deve ter a capacidade de articular ensino e pesquisa de forma indissociável e viabilizar a relação transformadora com a sociedade. É estender sua ação para fora de seus muros, interagindo com a comunidade, visando a troca de saberes. Neste sentido, a extensão universitária representa um aspecto fundamental do compromisso social das universidades, que segundo Chauí (2003) não estão conseguindo cumprir de forma ampla e satisfatória. Desta forma, é necessário que seja atribuída importância à extensão como função institucional de forma abrangente, considerando-a não somente como difusão de conhecimentos, mas como meio de inserção cultural e de educação para a vida e cidadania.

A gestão socialmente responsável, de acordo com Ribeiro (2013), refere-se às atitudes e procedimentos dos gestores e envolve atividades como planejamento, acompanhamento e avaliação de resultados do PDI. Por desempenhar papel tão estratégico para a sociedade, sua responsabilidade com seus ativos e a resposta dos anseios da comunidade devem ter prioridade, pois, segundo Elpo (2004), não existe outra organização com tanta responsabilidade no uso efetivo de modelos de gestão do que aquela que cria, teoriza, reproduz e produz estes modelos.

Para Sobrinho (2014), não há um modelo único de universidade, como também não há homogeneidade em seu interior, pois as contradições são inerentes aos fenômenos sociais. Também não há instituições prontas e acabadas, elas se transformam nos movimentos de seus processos de construção. Segundo Rizzatti \& Dobes (2004), são quatro os principais modelos teóricos de processo decisório em universidades: burocrático, colegiado, político e anárquico.

No modelo colegiado, por exemplo, de acordo com Machado \& Silveira (2008) as universidades adotaram como órgãos superiores deliberativos os Conselhos Universitários, de Curadores e de Ensino, Pesquisa e Extensão e, como órgão superior executivo a Reitoria, as PróReitorias, as Diretorias de unidade administrativas e os órgãos de apoio. No caso brasileiro, a colegialidade é estabelecida em lei, a partir da reforma de 1968. A Lei $\mathrm{n}^{\circ}$ 9.192, de 21 de dezembro de 1995, mantém esta estrutura e estabelece que ela seja composta, no mínimo, de setenta por cento por docentes.

A Figura 3 sintetiza as funções dos órgãos deliberativos e executivos.

Figura 3 - Funções dos órgãos deliberativos e executivos

\begin{tabular}{|c|c|c|c|}
\hline Categoria & Órgãos Superiores & Responsabilidade & Representantes \\
\hline \multirow{3}{*}{ Deliberativos } & Conselhos Universitários & Administração superior & $\begin{array}{l}\text { Reitor, Vice-reitor, Ex-reitores, Pró- } \\
\text { Reitores, representantes docentes e } \\
\text { discentes, Diretores de ensino, } \\
\text { Representantes da sociedade. }\end{array}$ \\
\hline & Conselho de Curadores & \begin{tabular}{|l|} 
Fiscalização \\
econômico-financeira
\end{tabular} & $\begin{array}{l}\text { Representantes da comunidade } \\
\text { acadêmica }\end{array}$ \\
\hline & $\begin{array}{l}\text { Conselho de Ensino, Pesquisa } \\
\text { e Extensão }\end{array}$ & $\begin{array}{l}\text { Supervisão e } \\
\text { coordenação destas } \\
\text { atividades }\end{array}$ & $\begin{array}{l}\text { Reitor, Vice-Reitor, Pró-Reitores das } \\
\text { áreas, Diretores de ensino, Docentes e } \\
\text { Discentes }\end{array}$ \\
\hline \multirow{4}{*}{ Executivos } & Reitoria & \multirow{4}{*}{$\begin{array}{l}\text { Superintendência de } \\
\text { todas as atividades } \\
\text { acadêmicas e } \\
\text { administrativas }\end{array}$} & Reitor, Vice-Reitor \\
\hline & \begin{tabular}{|l} 
Pró-Reitorias \\
\end{tabular} & & \begin{tabular}{|l} 
Pró-Reitores \\
\end{tabular} \\
\hline & Unidades de Ensino & & Diretores \\
\hline & Órgãos de apoio & & Docentes e técnicos \\
\hline
\end{tabular}

Fonte: adaptado de Machado e Silveira (2008).

Neste aspecto, percebe-se a responsabilidade com postura ética dos dirigentes da IES em conduzir suas ações pelo desenvolvimento sustentável da sociedade, orientando as relações pedagógicas e de trabalho em seu interior. A corresponsabilidade e a observância das decisões colegiadas fazem a administração solidária e o empreendedorismo se aliarem à qualidade e a interação social (Rösler \& Ortigara, 2005; Pinto, 2012).

\subsection{Teoria dos Stakeholders}

A teoria dos stakeholders foi inicialmente desenvolvida para a teoria de gestão estratégica, tendo como um dos principais precursores Richard E. Freeman, que publicou a obra Strategic Management: a Stakeholder Approach, em 1984. O termo stakeholder é empregado para designar as

Revista de Negócios, v. 23, n. 4, p. 7-24, October, 2018. 
partes interessadas, que podem ser qualquer grupo ou indivíduo que possa afetar ou ser afetado pelos objetivos da organização, incluindo tanto aquele que investe financeiramente na organização, como aquele que influencia de outras formas ou sofre as consequências das ações organizacionais (Macke \& Carrion, 2006; Hanashiro, Teixeira \& Zaccarelli, 2007; González, 2012).

O trabalho de Freeman, segundo Jamali (2008), contribuiu para reconceituar a natureza da empresa considerando novos stakeholders externos, além do elenco tradicional (acionistas, clientes, funcionários e fornecedores), legitimando novas formas de compreensão e ação. Os stakeholders, segundo esta definição, são entidades sociais (individuais ou coletivas) que têm no presente e no futuro algum tipo de influência capaz de afetar a realização dos objetivos da organização (Hanashiro, Teixeira \& Zaccarelli, 2007).

Para Mainardes et al. (2011), após o surgimento da teoria dos stakeholders na década de 1980 e o seu desenvolvimento na década de 1990, esta abordagem teórica ganhou espaço entre acadêmicos e profissionais da área da gestão como um novo modelo gerencial que considera, além de acionistas, funcionários, fornecedores e clientes, outros potenciais interessados nas atividades da organização.

As organizações são pressionadas, tanto pelos seus agentes externos como internos, a adotarem comportamentos que garantam sua sobrevivência e o desenvolvimento da sociedade em seu entorno, extrapolando os fatores econômicos e financeiros e considerando os aspectos éticos e sociais. Desta forma, as responsabilidades das organizações são ampliadas perante seus stakeholders, em relação às práticas empresariais que afetam o cotidiano das pessoas (Ashley, 2002; Oliveira, 2008).

Jamali (2008) argumenta que, a partir desta perspectiva, espera-se que as organizações administrem de forma responsável a rede de interesses de seus stakeholders, por meio de fronteiras permeáveis e que reconheçam o dever de cuidar dos grupos tradicionais e demais grupos, como as comunidades locais e o meio ambiente. A proposta de gerir sua responsabilidade, segundo González (2012), deve considerar que esta se define a partir do diálogo com todos os grupos da organização, buscando averiguar neste diálogo, quais interesses e valores são comuns, quais são próprios dos grupos e quais são interesses e valores individuais.

Para Villarreal (2014), a universidade se constitui como parte da sociedade e com ela estabelece interação dinâmica. Desta forma, tem como função prover os membros da comunidade de conhecimentos em todas as áreas, assim como, envolver os diferentes atores da sociedade nos âmbitos econômico, político e social. A responsabilidade social se desenvolve quando a organização toma consciência de si mesma, de seu entorno e do papel que representa (Vallaeys, 2006). Silva (2014) alega que a responsabilidade social universitária implica em dever ético e obrigação moral e epistemológica de internalizar as externalidades e não limitar a gestão a seus processos internos, sendo que a universidade não se comporte como sistema autista em relação ao seu entorno, gerando externalidades não administráveis.

O envolvimento das organizações com seus grupos de interesse pleiteia conhecimento para que se tenha relação construtiva para os envolvidos. Compreender as expectativas da sociedade se tornou essencial, devido à pressão exercida por grupos, direta ou indiretamente, ligados à organização. Estas pressões vão além da conduta social e ética, mas também está pautada em relação às ações de responsabilidade social (Junqueira \& Wada, 2011). Marchiori (2010) expõe que é por meio da comunicação que as organizações são possíveis, por estabelecer o elo entre os seus elementos, que deixam de estar isolados e desorganizados.

O processo de interação e a comunicação exercem, para Paula \& Mendonça (2014), um papel primordial para satisfazer a maioria das necessidades humanas, permitindo a transmissão das informações a respeito de ideias, sentimentos e intenções. A gestão de imagem socialmente responsável perpassa pelos canais de interação da organização com os stakeholders.

A imagem institucional decorre da missão estratégica das organizações e é fruto da percepção de seus grupos de interesse. Uma imagem divergente dos propósitos institucionais, quando detectado, sinaliza que investimentos e estratégia não estão sendo empregados adequadamente. Não perder de vistas a estratégia adotada e angariar esforços para o seu desenvolvimento são aspectos fundamentais para a gestão coerente com os propósitos institucionais (Piñol, 2004). O significado da imagem para a organização e sua

Revista de Negócios, v. 23, n. 4, p. 7-24, October, 2018. 
administração incide em suas atitudes sociais, pois a robustez da imagem está relacionada diretamente com a consistência e coerência entre o discurso e ações (Kotler, 2013).

De acordo com Vallaeys, Cruz e Sasia (2009), o fechamento do ciclo da responsabilidade social passa pela prestação de contas das ações desenvolvidas aos stakeholders da organização. Esta premissa de transparência e comunicação das ações está se transformando num valor moral e palavra chave quando se discute responsabilidade social de forma geral. Os autores enfatizam que as universidades não são obrigadas a reportar à sociedade suas ações de responsabilidade social como as empresas, porém trazem cinco argumentos, nos quais a prestação de contas pode trazer benefícios:

a) Gerar confiança e entusiasmo na universidade, no sentido de dizer o que se faz e fazer o que se diz;

b) Reconhecer e valorizar as boas práticas das pessoas e das áreas da instituição, para assim também servirem de exemplo;

c) Fomentar a responsabilidade de cada membro e do conjunto da universidade pela excelência de ações empreendidas e da melhoria contínua (ao se declarar o que faz, gera compromisso de melhorá-lo);

d) Permitir a autocrítica institucional e identificar deficiências (a universidade dizer o que é certo e o que não é para refletir sobre o seu desempenho e projetar metas para o futuro), e;

e) Dar sustentabilidade ao sistema organizacional da universidade, pois ao publicar o que se faz, a instituição se compromete com o desenvolvimento futuro.

Assim o processo de reportar e de prestar contas oferece também subsídios para a autoaprendizagem institucional e para a consolidação do compromisso com a responsabilidade social, não sendo um mero recurso informativo para a universidade. Isto significa não só mencionar as conquistas, mas também os pontos críticos e fracos, que fazem o relatório ganhar credibilidade (não é uma propaganda institucional) e utilidade (é uma ferramenta de melhoria) (Vallaeys, Cruz \& Sasia, 2009).

\section{Metodologia}

A pesquisa caracteriza-se como um estudo exploratório, visto que se realiza a sondagem sobre o significado de responsabilidade social universitária. Para Vergara (2013), a investigação exploratória é efetuada em área na qual há pouco conhecimento acumulado e sistematizado e não comporta hipóteses, devido sua natureza.

Quanto à abordagem do problema, esta pesquisa caracteriza-se como qualitativa. Para Denzin \& Lincoln (2006), a pesquisa qualitativa implica ênfase sobre as qualidades das entidades e sobre os processos e os significados que não são examinados ou medidos em termos de quantidade, volume, intensidade ou frequência. Quanto a estratégia da pesquisa, trata-se de um estudo de caso único por abordar uma IES, a FURB. O estudo de caso que se concentra na compreensão da dinâmica apresentada dentro de uma única configuração, na qual a investigação empírica analisa um fenômeno no seu contexto real, buscando apreciar sua singularidade, complexidade e sua interação com o contexto (Eisenhardt, 1989; Stake, 1995; Yin, 2009).

$\mathrm{O}$ universo desta pesquisa se constituiu de todos os stakeholders da FURB, sendo: alunos, servidores técnico-administrativos, professores, egressos, comunidade externa, fornecedores, prefeitura, instituições parceiras, órgãos de fomento e MEC. A amostra da pesquisa se compõe por 23 membros do Conselho Universitário da FURB, entre eles, três com representantes da comunidade externa, duas com representantes dos técnicos-administrativos, duas com discentes, cinco com diretores de unidades de ensino, cinco com membros da gestão superior, quatro com docentes, uma com o representante do sindicato e uma com o representante dos servidores inativos. $\mathrm{O}$ Conselho Universitário é composto pelos principais grupos de interesse da Instituição.

A coleta de dados foi realizada por meio de entrevistas e documentos institucionais. A entrevista foi realizada com os 23 membros do Conselho Universitário da FURB. Antes do início da entrevista, os participantes leram e assinaram o Termo de Consentimento Livre e Esclarecido (TCLE) aprovado pelo Comitê de Ética da FURB, com as informações do projeto e autorização de gravação e transcrição das entrevistas. Desta forma, as entrevistas foram gravadas com auxílio de gravador digital e fez-se a transcrição na íntegra. Cada entrevista teve duração média de 40 minutos. A realização da coleta de dados aconteceu entre os dias 23 de março e 5 de maio de 2015.

Revista de Negócios, v. 23, n. 4, p. 7-24, October, 2018. 
Os documentos institucionais foram utilizados na análise para complementar e enriquecer os dados obtidos pelas entrevistas, pois de acordo com Vergara (2013), estes documentos representam o sistema e a estrutura da organização. Neste quesito, a análise compreendeu documentos de conhecimento geral, tais como o PDI, estatutos e regimentos, disponíveis no endereço eletrônico, intranet e documentos impressos.

Para a análise das entrevistas optou-se pela categorização, pois significa operação de classificação de elementos constitutivos de um conjunto por diferenciação, na qual ocorre $o$ desmembramento do texto em unidades e, posteriormente por reagrupamento conforme critérios pré-definidos. A Figura 4 apresenta as categorias de análise da pesquisa.

Figura 4 - Categorias norteadoras da pesquisa.

\begin{tabular}{|c|c|c|}
\hline Categorias iniciais & Categorias finais & Definiç̃ão \\
\hline $\begin{array}{l}\text {-Conceito de } \\
\text { responsabilidade social }\end{array}$ & $\begin{array}{l}\text { Responsabilidade } \\
\text { Social } \\
\text { Universitária }\end{array}$ & $\begin{array}{l}\text { Conjunto de respostas da universidade para a sociedade na } \\
\text { qual está inserida. Tais respostas dizem respeito à } \\
\text { contribuição com o desenvolvimento social, cultural, } \\
\text { sustentável e econômico (RIBEIRO, 2013). }\end{array}$ \\
\hline \begin{tabular}{|l|}
-ensino \\
-pesquisa \\
-extensão \\
-gestão
\end{tabular} & $\begin{array}{l}\text { Impactos } \\
\text { Universitários }\end{array}$ & $\begin{array}{l}\text { Impactos gerados pela universidade: organizacionais } \\
\text { (gestão); educativos (formação acadêmica); sociais } \\
\text { (extensão); e cognitivos (investigação) (VALLAEYS; } \\
\text { CRUZ; SASIA, 2009). }\end{array}$ \\
\hline $\begin{array}{l}\text {-papel da FURB } \\
\text {-comunicação } \\
\text {-atendimento das } \\
\text { demandas da sociedade } \\
\text {-relacionamento com } \\
\text { grupos de interesse }\end{array}$ & $\begin{array}{l}\begin{array}{l}\text { Relação com } \\
\text { sociedade }\end{array} \\
\end{array}$ & $\begin{array}{l}\text { A responsabilidade social se desenvolve quando a } \\
\text { organização toma consciência de si mesma, de seu entorno e } \\
\text { do papel que representa (VALLAEYS, 2006). }\end{array}$ \\
\hline
\end{tabular}

Fonte: Dados da pesquisa.

Para a análise dos dados, após as transcrições das entrevistas, adotou-se a análise de conteúdo, que, de acordo com Bardin (2009), consiste em técnicas de análise de comunicação visando obter indicadores (quantitativos ou não) que permitam a inferência de conhecimentos relativos às condições de produção e recepção das mensagens. As entrevistas foram divididas em documentos separados pelas categorias iniciais estabelecidas, dos quais se extraiu as unidades de registro por meio de palavras, frases ou parágrafos.

\section{Apresentação e análise dos resultados}

A apresentação dos resultados seguirá nas próximas sessões conforme categorias finais da pesquisa: Responsabilidade Social Universitária, Impactos Universitários e Relação com a comunidade.

\subsection{Responsabilidade Social Universitária}

A seguir, na Figura 5 apresentam-se os principais pontos levantados pelos entrevistados da pesquisa quanto ao conceito de responsabilidade social.

Figura 5 - Unidades de registro sobre o conceito de responsabilidade social.

\begin{tabular}{|c|c|}
\hline $\begin{array}{l}\text { Unidades de } \\
\text { registro }\end{array}$ & Relato na entrevista \\
\hline $\begin{array}{c}\text { Conceito amplo e } \\
\text { complexo }\end{array}$ & $\begin{array}{l}\text { "[...] a responsabilidade social ela é muito abrangente e muito ampla. Ela assume } \\
\text { caracteristicas de cidadania, de comunidade, de uma sociedade ampla." (Entrevistado 23) }\end{array}$ \\
\hline Ação individual & $\begin{array}{l}\text { "Responsabilidade social é a gente direcionar nossos atos de uma forma que não } \\
\text { prejudiquem ou que tirem da sociedade os seus direitos e seus beneficios." (Entrevistado } \\
\text { 22) }\end{array}$ \\
\hline $\begin{array}{c}\text { Ação das } \\
\text { organizações }\end{array}$ & $\begin{array}{l}\text { "Para mim é o objetivo que uma determinada instituição, privada ou pública, tem em } \\
\text { relação à sociedade, [... [." (Entrevistado 6) }\end{array}$ \\
\hline $\begin{array}{l}\text { Beneficio } \\
\text { coletivo }\end{array}$ & $\begin{array}{l}\text { "A relação dela com a comunidade, as respostas que ela tem que dar aos problemas da } \\
\text { comunidade [...]." (Entrevistado 14) }\end{array}$ \\
\hline Regionalismo & $\begin{array}{l}\text { "[...] da nossa sociedade, da nossa cidade [..] propósito alinhado com a perspectiva de um } \\
\text { crescimento sustentável economicamente e socialmente da cidade onde a gente vive". } \\
\text { (Entrevistado 2) }\end{array}$ \\
\hline $\begin{array}{l}\text { Aspecto social, } \\
\text { econômicoe } \\
\text { ambiental }\end{array}$ & $\begin{array}{l}\text { "Tem a ver tanto na parte sustentável, ter bom senso das pessoas e na parte financeira, } \\
\text { porque se você tem um padrão econômico, você vai estar ajudando para responsabilidade } \\
\text { social, para a instituição fomentar esta parte social." (Entrevistado 17) }\end{array}$ \\
\hline $\begin{array}{l}\text { Além das } \\
\text { obrigações }\end{array}$ & $\begin{array}{l}\text { "São todas aquelas ações que um indivíduo ou uma empresa tomam no sentido, não para } \\
\text { trabalhar na sua produção, mas no bem estar geral, das pessoas e do meio ambiente, de } \\
\text { todas as questões que envolvem a sociedade." (Entrevistado 12) }\end{array}$ \\
\hline $\begin{array}{l}\text { Relação com a } \\
\text { sociedade }\end{array}$ & $\begin{array}{l}\text { "É a essência da universidade, a relação dela com a comunidade, as respostas que ela tem } \\
\text { que dar aos problemas da comunidade." (Entrevistado 14) }\end{array}$ \\
\hline $\begin{array}{l}\text { Comportamento/ } \\
\text { atitude }\end{array}$ & $\begin{array}{l}\text { "E não é modismo, não é mudança, é uma transição e veio para ficar, mas ela tem que ser } \\
\text { compreendida e isso é um processo gradual, lento [...] mudança gradual de } \\
\text { comportamento para que digamos: a gente tem um mundo sustentável." (Entrevistado } \\
\text { 22) }\end{array}$ \\
\hline
\end{tabular}

Fonte: Dados da pesquisa.

O caráter amplo e complexo do conceito sobre responsabilidade social é corroborado no decorrer das entrevistas, das quais são identificadas diversas características relacionadas ao conceito. Este aspecto é confirmado por Cruvinel (2008), ao alegar a falta de consenso sobre o conceito de responsabilidade social e seus limites e, desta forma, configura-se como objeto de disputa. Para Melo Neto \& Froes (2001) a maior dificuldade para definir responsabilidade social está na amplitude do tema e, assim, na extensão do seu espectro. Álvarez \& Liarti (2012) relatam que a responsabilidade social é uma expressão que tomou força nos últimos anos na agenda econômica e empresarial e, posteriormente, política e social, porém existem vários termos a ela associados sem alcançar um conceito único, o que repercute no momento de estabelecer estratégias e direções.

Conforme a Figura 5, os entrevistados, ao relatarem sobre o conceito de responsabilidade social, associaram a ação de si próprio ou de forma impessoal como "a gente" ou "você" perante a sociedade, demonstrando o entendimento de que a responsabilidade parte da ação individual para a coletiva. Em termos gerais, a responsabilidade de um agente se refere à obrigação de responder pelas consequências previsíveis de suas ações em virtude de leis, contratos, normas de grupos sociais ou de sua convicção íntima, sendo a capacidade de escolha das ações uma condição básica para o surgimento da responsabilidade desses agentes (Barbieri \& Cajazeira, 2009). Este entendimento pode ser inferido devido à característica dos

Revista de Negócios, v. 23, n. 4, p. 7-24, October, 2018. 
respondentes, que estão inseridos num ambiente universitário, com características sociais, no qual a consciência de um olhar para a sua própria contribuição para sociedade seja mais evidente.

Os campos de responsabilidade social identificados pelos respondentes abarcaram questões sociais, econômicas e ambientais. Neste sentido, para estes entrevistados a responsabilidade social está mais ligada ao aspecto social, da relação do indivíduo ou da organização com a sociedade, sendo lembrada por todos entrevistados. No entanto, as questões ambientais e econômicas foram mencionadas em nove relatos, confirmando conforme Elkington (1997) que as responsabilidades voltam-se para a sustentabilidade da sociedade por meio do triple botton line (social, ambiental e econômico).

\subsection{Impactos Universitários}

As Figuras 6, 7, 8 e 9 apresentam as principais considerações dos entrevistados no que tange aos impactos gerados pela universidade: educativos (formação acadêmica); cognitivos (investigação); sociais (extensão) e organizacionais (gestão).

Figura 6 - Unidades de registro sobre a atividade de ensino.

\begin{tabular}{|c|c|}
\hline $\begin{array}{l}\text { Unidades de } \\
\text { registro }\end{array}$ & Relato na entrevista \\
\hline $\begin{array}{c}\text { Atividade } \\
\text { principal }\end{array}$ & $\begin{array}{l}\text { "Então o ensino é a base de tudo, que é tu ter o conhecimento." (Entrevistado б) } \\
\text { "[...] o ensino é o primeiro ponto, que é a transmissão do conhecimento conhecido que é o } \\
\text { primeiro fator." (Entrevistado 21) }\end{array}$ \\
\hline Formação & $\begin{array}{l}\text { "Quando fala em ensino, fala em formação, no repasse de conhecimento, na aprendizagem. } \\
\text { Então todos estes temas aqui fazem parte de várias áreas de conhecimento que temos na } \\
\text { universidade." (Entrevistado o) } \\
\text { "Então na formação do próprio, do próprio profissional da graduação já vai imbuida a ideia } \\
\text { de que ele está sendo formado para atender, não digo o mercado, mas para atender a } \\
\text { sociedade que precisa que aquele profissional tenha na sua formação, não exclusivamente, } \\
\text { o dominio, os conteúdos que a sociedade precisa, senão nós vamos formar pessoas } \\
\text { completamente dissociadas com aquilo que o mercado ou a sociedade precisa." } \\
\text { (Entrevistado l4) }\end{array}$ \\
\hline Qualidade & $\begin{array}{l}\text { "E a qualidade do ensino nem se fala, com o professor, com um bom contédo, forma } \\
\text { alguém, forma cidadãos e isto é muito importante do ponto de vista social." (Entrevistado } \\
\text { 12) } \\
\text { "A universidade ela não recebe o cidadão completo, ele está em formação, naturalmente } \\
\text { então essa responsabilidade de dar qualidade ao trabalho, ao serviço que presta é } \\
\text { fundamental." (Entrevistado 23) }\end{array}$ \\
\hline $\begin{array}{l}\text { Deficiências do } \\
\text { ensino }\end{array}$ & $\begin{array}{l}\text { "[...] senão nós vamos formar pessoas completamente dissociadas com aquilo que o } \\
\text { mercado ou a sociedade precisa. Então eu diria para você ainda, que nós precisamos fazer } \\
\text { uma análise bastante importante mesmo no nosso PDI e colocar um indicador de } \\
\text { transferência do que a universidade faz para a sociedade para que você possa, antes de } \\
\text { discutir a responsabilidade propriamente dela, que é uma questão macro, saber se ela } \\
\text { efetivamente está praticando isso." (Entrevistado 14) }\end{array}$ \\
\hline
\end{tabular}

Fonte: Dados da pesquisa.

A atividade de ensino foi identificada como sendo a principal atividade de uma IES, cuja função é a formação do estudante por meio da aprendizagem para atender a sociedade. Esta também é a posição de Durham (2005) ao alegar ser esta a atividade mais fundamental a se exigir de qualquer instituição de ensino.

Quanto à qualidade do ensino, Rösler e Ortigara (2005) argumentam ser este o maior desafio para a educação, que é responsabilidade de todos: família, Estado e sociedade. Quanto ao professor que busca qualidade em sala de aula, será estimulado pelos resultados obtidos, terá energia para sua sobrevivência, não se deixará abater, colocará a dignidade de ser bom profissional como prioridade, de modo que se sinta recompensado pelo que faz. Esta compreensão é compartilhada por diversos entrevistados, ao considerarem esta a principal responsabilidade social relacionada à atividade.

A Figura 7 apresenta o relato dos entrevistados relativos a atividade de pesquisa.

Figura 7 - Unidades de registro sobre a atividade de pesquisa.

\begin{tabular}{|c|c|}
\hline $\begin{array}{c}\text { Unidades de } \\
\text { registro }\end{array}$ & Relato na entrevista \\
\hline $\begin{array}{l}\text { Pouca } \\
\text { visibilidade }\end{array}$ & $\begin{array}{l}\text { "A pesquisa não é tão visível, existem vários grupos, mas falta divulgar as pesquisas que } \\
\text { são feitas. Até os docentes terminam seu doutorado e mestrado e não têm espaço para } \\
\text { divulgar suas pesquisas." (Entrevistado l) } \\
\text { "Na pesquisa efetivamente eu não tenho contato, eu não sei de fato o que acontece lâ." } \\
\text { (Entrevistado 7) }\end{array}$ \\
\hline Relacionamento & $\begin{array}{l}\text { "[...] são desenvolvidos trabalhos que de certa forma estão relacionadas à importância } \\
\text { social da universidade junto à comunidade e ao Brasil." (Entrevistado 12) } \\
\text { "Nós temos o ensino, a pesquisa ela vem sendo desenvolvida ao longo do tempo, mas ela } \\
\text { é muito fragmentada, pouco compartilhada e poucas vezes associada às demandas da } \\
\text { sociedade, é mais as demandas do pesquisador e na competência dele." (Entrevistado } \\
\text { 18) }\end{array}$ \\
\hline Reconhecimento & $\begin{array}{l}\text { "[...] } \text { somos reconhecidos pela pesquisa que é desenvolvida aqui dentro." (Entrevistado } \\
\text { 12) }\end{array}$ \\
\hline
\end{tabular}

Fonte: Dados da pesquisa.

Na Figura 7 também se observa dois opostos apontados pelos entrevistados: por um lado observa-se que a pesquisa é a atividade que não é tão percebida e reconhecida, por outro se vislumbra o reconhecimento da atividade da instituição. Estes opostos foram levantados por grupos específicos dos entrevistados: os que estão relacionados com a atividade, seja na administração superior ou em seu setor, e reconhecem a importância e relevância das pesquisas realizadas pela FURB, em âmbito nacional e também internacional; e pelo grupo formado por entrevistados que não possuem o envolvimento direto com a atividade. Guimarães (2002) ressalta a importância da atividade de pesquisa para a vida acadêmica, no entanto, é necessário rever seu papel e o modo de inserção dessa atividade na universidade.

A Figura 8 apresenta os principais relatos dos entrevistados da pesquisa relativos a atividade de extensão realizados na FURB.

Conforme exposto na Figura 8, a extensão universitária na FURB foi a atividade em que os entrevistados mostraram maior conhecimento dos projetos e programas desenvolvidos, o que confirma os argumentos de Macedo (2005), nos quais o papel da extensão universitária adquire paulatinamente importância igual à do ensino e da

Revista de Negócios, v. 23, n. 4, p. 7-24, October, 2018. 
pesquisa, além de Schwartzman (2005) ao alegar que quando se pensa em responsabilidade social em IES, liga-se às atividades de extensão. No entanto, os entrevistados admitem que a FURB poderia ampliar os serviços oferecidos.

Figura 8 - Unidades de registro sobre a atividade de extensão.

\begin{tabular}{|c|c|}
\hline $\begin{array}{l}\text { Unidades de } \\
\text { registro }\end{array}$ & Relato na entrevista \\
\hline $\begin{array}{l}\text { Atividade na } \\
\text { qual a } \\
\text { responsabilidade } \\
\text { social é mais } \\
\text { percebida }\end{array}$ & $\begin{array}{l}\text { "Eu acho que a FURB vem prestando um serviço de grande valia para a comunidade nestes } \\
\text { últimos tempos." (Entrevistado 9) } \\
\text { "A extensão parece ser num primeiro momento a atividade onde a responsabilidade social } \\
\text { aflora muito mais." (Entrevistado 12) }\end{array}$ \\
\hline $\begin{array}{l}\text { Atividades } \\
\text { lembradas }\end{array}$ & $\begin{array}{l}\text { Atelier Vertical; Centro de Inovação; Centro de Operação de Sistema de Alerta (CEOPS); } \\
\text { Cultura, Formar multiplicadores na area de educaçãóatental; FURB FM; FURB Móvel } \\
\text { (Odontologia); FURB TV; FURB Visita sua Rua; Hospital Universitário; Hospital } \\
\text { Veterinário; Interação; Inventário Floristico; Incubadora Tecnológica de Cooperativas } \\
\text { Populares (ITCP); Núcleo de Estudos Afro-brasileiro (NEAB); Núcleo de Estudos } \\
\text { Indigenas (NEI); Núcleo de Prática Jurídica (NPJ); Projeto com a Suécia; Semana } \\
\text { Acadêmica; Transferência de gestáo de residuos sólidos; Vida e Saúde Pomerode. }\end{array}$ \\
\hline Ampliação & $\begin{array}{l}\text { "Entendo que a FURB podia avançar muito mais nestas questões." (Entrevistado l1) } \\
\text { "Alguns projetos de extensão, não conheço muito a fundo eles, mas também já tem uma } \\
\text { aproximação, mas pelos } 50 \text { anos de FURB, eu acho que ainda poderia avançar muito nesta } \\
\text { questão social." (Entrevistado 19) } \\
\text { "Eu acho a extensão pouco valorizada na realidade, ela não tem um peso [...]Tem o peso } \\
\text { por ser um dos tripés, mas eu não vejo na FURB uma politica de extensão consistentes, } \\
\text { com valorização dos que fazem extensão mais forte." (Entrevistado 20) }\end{array}$ \\
\hline $\begin{array}{l}\text { Relacionamento } \\
\text { externo }\end{array}$ & $\begin{array}{l}\text { "Extensão da mesma forma, ela tem resultados já históricos que a FURB teve junto a sua } \\
\text { comunidade e nós temos que equalizar como nós executamos estas demandas de acordo } \\
\text { com o perfil de cada comunidade." (Entrevistado 18) } \\
\text { "Eu acho que a extensão é um caminho para aproximar a academia enfim, a universidade } \\
\text { até a população. [..] É a comunidade que tem que sinalizar as suas necessidades e a a } \\
\text { instituição a partir disso viabilizar, criar com os seus profissionais estes projetos." } \\
\text { (Entrevistado 19) }\end{array}$ \\
\hline
\end{tabular}

Fonte: Dados da pesquisa.

A Figura 9 apresenta o relato dos entrevistados no tocante a gestão universitária da FURB.

Figura 9 - Unidades de registro sobre gestão universitária.

\begin{tabular}{|c|c|}
\hline $\begin{array}{c}\text { Unidades } \\
\text { de registro }\end{array}$ & Relato na entrevista \\
\hline Colegiado & 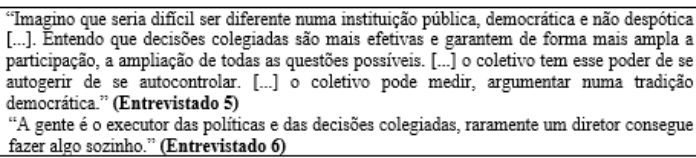 \\
\hline Político & $\begin{array}{l}\text { "Sãa várias linhas de pensamento, várias ideologias internas, a gente sente isso no CONSUNI. } \\
\text { Eu participo e os debates estão muitos alinhados a questóes ideológicas." (Entrevistado 2) } \\
\text { "E um ambiente politico forte, muito forte, [...] bandeiras que ali existem, pelo menos que eu } \\
\text { venho percebendo até agora não se sobrepõe aos interesses maiores." (Entrevistado 9) }\end{array}$ \\
\hline Anárquico & $\begin{array}{l}\text { "Nós temos as nossa dores, os nosso amores, os nossos conceitos diferentes, os nossos conflitos } \\
\text { diferentes e nessa sopa toda de sujeitos a gente tenta se definir, a gente tenta procurar uma saida } \\
\text { resolver problemas e muitas vezes de formas diferentes, e muitas vezes com conceitos } \\
\text { diferentes." (Entrevistado } 3 \text { ) } \\
\text { "OO CEPE é muito interesse, todo mundo tem seu interesse próprio, eles não tem o interesse } \\
\text { coletivo, o interesse da instituição, a maioria destes conselhos é interesse individualista, e ai } \\
\text { não espalha [...] é um individualismo muito grande." (Entrevistado 8) } \\
\text { "Que se tomem decisões mais claras e aplicadas iguais para todos [...] isso causa bastante } \\
\text { confusâo, transtorno e atrasa bastante os processos [...] principalmente no CEPE eu vejo isso } \\
\text { com relatores. Então se aplica uma regra num caso, em outro caso se segue aquela regra e o } \\
\text { outro relator diz que não é assim." (Entrevistado 10) }\end{array}$ \\
\hline $\begin{array}{l}\text { Falta de } \\
\text { agilidade na } \\
\text { decisão }\end{array}$ & $\begin{array}{l}\text { "Não é uma instituição ágil e erápida. Tem que ser um processo mais dinâmico, mais rápido } \\
\text { para resolver estas questôes. [....E mua instituiçãa muito quadradinha, dentro da forma eprecisa } \\
\text { se abrir um pouco mais. Eu acho que a FURB esta perdendo este andar da carruagem." } \\
\text { (Entrevistado 2) } \\
\text { "Comissões que existem aí pela FURB, que às vezes não caminham, são estéreis em si } \\
\text { mesmo." (Entrevistado 9) } \\
\text { "[...] às vezes para aprovar um projeto demora muitas sessões." (Entrevistado 17) }\end{array}$ \\
\hline $\begin{array}{l}\text { Falta de } \\
\text { capacitação }\end{array}$ & $\begin{array}{l}\text { "Pelo critério de escollha, acho que a gente deveria ter pessoas com mais tempo, mais titulação } \\
\text { formal, que tivessem passado por situacôes de gestão, acho que isso ajudaria. [...] às vezes tem } \\
\text { conselheiro que não tem ideia do que se está falando, aí fica dificil, aí a gente teria que } \\
\text { qualificar o conselho." (Entrevistado 13) }\end{array}$ \\
\hline
\end{tabular}

Fonte: Dados da pesquisa.

Segundo Rizzatti \& Dobes (2004) são quatro os principais modelos teóricos de processo decisório em universidades: burocrático, colegiado, político e anárquico, Porém Ellströn (2007) e Pinheiro (2011) afirmam que os quatro modelos são passíveis de coexistência no contexto universitário. Desta forma, buscou-se identificar se características destes modelos estão presentes na FURB, e conforme depoimentos dos entrevistados na Figura 6 viu-se que sim, os quatro modelos podem ser identificados dentro da instituição. $\mathrm{O}$ modelo burocrático é explicitado pelo organograma da FURB. Além disso, os entrevistados destacam também as dificuldades para que decisões mais ágeis sejam tomadas. O modelo de tomada de decisão oficialmente adotado é o colegiado, que, segundo os entrevistados, mostra-se adequado para atender aos objetivos da Instituição, devido ao modo democrático e participativo como são tomadas as decisões. Para Rizzatti \& Dobes (2004), o modelo colegiado defende a ideia de participação da comunidade acadêmica, na qual as decisões são tomadas em consenso.

\subsection{Relação com a sociedade}

A responsabilidade social se desenvolve quando a organização toma consciência de si mesma, de seu entorno e do papel que representa (Vallaeys, 2006). A seguir, nas Figuras 10, 11, 12 e 13 apresentam-se os resultados relativos a relação da FURB com a sociedade.

Figura 10 - Unidades de registro sobre o papel da FURB para a região.

\begin{tabular}{|c|c|}
\hline $\begin{array}{l}\text { Unidades de } \\
\text { registro }\end{array}$ & Relato na entrevista \\
\hline Reconhecimento & $\begin{array}{l}\text { "Papel é grandioso [...] eu acho que a FURB é a instituição mais bem vista pela sociedade, } \\
\text { no sentido de primar pela qualidade do ensino." (Entrevistado l) } \\
\text { "Eu acho que é essa formação de referência intelectual. Eu acho que toda a região nos vê } \\
\text { desta maneira. Eu acho que é isso que eles esperam da gente, dessa qualidade técnica de } \\
\text { resposta." (Entrevistado 10) }\end{array}$ \\
\hline $\begin{array}{l}\text { História da } \\
\text { cidade }\end{array}$ & $\begin{array}{l}\text { "Eu considero essencial e eu não sou de Blumenau [...] quando eu vejo como é a cidade } \\
\text { de Blumenau e como é a FURB, acho dificil imaginar Blumenau sem a FURB." } \\
\text { (Entrevistado 5) }\end{array}$ \\
\hline $\begin{array}{l}\text { Desenvolvimento } \\
\text { regional }\end{array}$ & $\begin{array}{l}\text { "A FURB é fundamental, não só de formação, mas de transformação da sociedade. Na } \\
\text { época de enchente a FURB é referência, as pessoas ficam esperando a TV da FURB, a } \\
\text { rádio, o que vai acontecer, o proprio sistema de gerenciamento, mas ao mesmo tempo } \\
\text { ninguém sabe que é a FURB que faz." (Entrevistado 13) }\end{array}$ \\
\hline Expectativas & $\begin{array}{l}\text { "Ela tem proporcionar aquilo que todo cidadão busca que é uma qualidade de vida, ela } \\
\text { tem que viabilizar ser um meio para que aquele cidadão que hoje está numa situação de } \\
\text { busca de conhecimento, de uma melhor qualificação profissional, ou que tem uma certa } \\
\text { formaçãao." (Entrevistado 19) }\end{array}$ \\
\hline
\end{tabular}

Fonte: Dados da pesquisa.

Segundo Vallaeys (2006) a responsabilidade social se desenvolve quando a organização compreende o papel que representa ao seu entorno. Neste sentido, obteve-se a categoria inicial o papel da FURB para a região, para entender qual é a relevância da presença da FURB no desenvolvimento da região em seus 51 anos de existência.

Observa-se que a história da FURB se confunde com a história de Blumenau e região,

Revista de Negócios, v. 23, n. 4, p. 7-24, October, 2018. 
sendo considerada um marco do desenvolvimento regional desde a década de 1960, que por iniciativa da sociedade pleiteou pela interiorização do ensino superior em Santa Catarina.

Contudo, nota-se que passados 51 anos, a expectativa de maior atuação e contribuição também está presente nas entrevistas observadas na Figura 10, das quais foi identificada a unidade de registro expectativas, ou seja, quais são os novos caminhos que a FURB deve desenvolver para continuar com sua contribuição, haja vista que outras IES também estão ocupando o espaço de ensino superior na região, conforme observado pelos entrevistados 2 e 7: "Se a gente pegar o Vale do Itajaí, Blumenau é uma referência, não só a FURB, mas a UNIASSEVI, a FFM, Bom Jesus, IBES Sociesc" (Entrevistado 2); "Outras IES foram entrando em Blumenau e cada um tem seu espaço e é certo que seja assim" (Entrevistado 7).

A Figura 11 apresenta o relato dos entrevistados referente ao atendimento das demandas da sociedade pela FURB.

Figura 11 - Unidades de registro sobre o atendimento das demandas da sociedade.

\begin{tabular}{|c|c|}
\hline $\begin{array}{l}\text { Unidades de } \\
\text { registro }\end{array}$ & Relato na entrevista \\
\hline Qualificação & $\begin{array}{l}\text { "A necessidade a principio, a meu ponto de ver, a primeira era gerar novos profissionais } \\
\text { de ensino superior, neste sentido a FURB cumpre e vem sempre cumprindo com novos } \\
\text { cursos." (Entrevistado 3) }\end{array}$ \\
\hline $\begin{array}{l}\text { Desenvolvimento } \\
\text { da sociedade }\end{array}$ & $\begin{array}{l}\text { "Eu acho que a FURB tem um papel importante na região, um reconhecimento grande } \\
\text { dessa formação, como universidade cumpre esse papel bem importante." (Entrevistado } \\
\text { 5) } \\
\text { "A FURB foi um dos grandes propulsores da economia não só em Blumenau, mas para } \\
\text { o Vale do Itajai e ela faz muito bem." (Entrevistado 21) }\end{array}$ \\
\hline Maior participação & $\begin{array}{l}\text { "A gente tem vários projetos de extensão que estão acontecendo, mas não vejo grande } \\
\text { comunicação a esse respeito e isso acaba retirando a importância da coisa." } \\
\text { (Entrevistado 7) } \\
\text { "Então ela está muito intramuros, ela tem que sair para outros lugares, para outras } \\
\text { cidades." (Entrevistado 14) }\end{array}$ \\
\hline $\begin{array}{l}\text { Expectativa de } \\
\text { atendimento }\end{array}$ & $\begin{array}{l}\text { "A FURB poderia aumentar esta parte social em conseguir talvez as licenciaturas } \\
\text { gratuitas para a sociedade em parceria com a Prefeitura Municipal de Blumenau, para } \\
\text { que ela possa ser mais participativa com a sociedade."(Entrevistado 17) } \\
\text { "Aggora eu acho que a FURB, ela poderia atuar mais na área de aconselhamento, de } \\
\text { aconselhamento inclusive politico, que no fundo tudo é uma ação politica." } \\
\text { (Entrevistado 23) }\end{array}$ \\
\hline
\end{tabular}

Fonte: Dados da pesquisa.

O entendimento dos entrevistados sobre as demandas da sociedade, conforme Figura 11, está relacionado com a qualificação profissional e o desenvolvimento da sociedade, também constatados por Jugón \& Corral (2012), que defendem que a universidade deve ter como tarefa formar pessoas no sentido humano e profissional e contribuir na construção de novos conhecimentos.

Novamente há expectativa de novos direcionamentos para a Instituição em relação à sua interação com a sociedade, da qual se espera maior participação e maior amplitude do atendimento das demandas da sociedade, conforme pode ser observado pelas unidades de registro nomeadas como "maior participação" e "expectativa de atendimento", o que é apoiado por Pinto (2012) ao alegar que as instituições devem aprender a escutar as demandas que vêm de fora de seus muros, e com os achados Rosetto \& Brito (2013), que identificaram que as universidades estão historicamente habituadas a se isolar.

A comunicação é o processo em que as organizações prestam contas à sociedade de seus resultados e impactos gerados, e notaram-se ruídos neste sentido, nos quais os entrevistados desconhecem as ações praticadas pela Instituição em diversas atividades e alegaram que não há uma comunicação efetiva. Para González (2012), a organização somente conseguirá legitimidade e credibilidade de seus stakeholders quando for capaz de responder às suas expectativas $\mathrm{e}$ comunicar suas ações de forma transparente. Neste sentido, foram trabalhadas as categorias iniciais 'relacionamento com os grupos de interesse' e 'comunicação', conforme apresentado na Figura 12 e 13.

Figura 12 - Unidades de registro sobre o relacionamento com os grupos de interesse.

\begin{tabular}{|c|l|}
\hline $\begin{array}{c}\text { Unidades de } \\
\text { registro }\end{array}$ & \multicolumn{1}{|c|}{ Relato na entrevista } \\
\hline $\begin{array}{c}\text { Não se } \\
\text { relaciona }\end{array}$ & $\begin{array}{l}\text { "Muito pouco, muito pouco. Diretamente eu diria que quase nenhuma, não só minha, mas } \\
\text { dos demais representantes [...] O CONSUNI é um aglomerado de pessoas responsáveis, mas } \\
\text { que é muito fechado em si, ele não tem abertura necessária." (Entrevistado 23) }\end{array}$ \\
\hline & $\begin{array}{l}\text { "Sempre que eu tenho oportunidade eu divulgo. Principalmente para os colegas de trabalho } \\
\text { e quando apropriado e cabivel, na sala de aula. Sempre converso com os alunos, como } \\
\text { coordenador de curso deixo eles a par do que a FURB faz e do que está acontecendo." }\end{array}$ \\
$\begin{array}{c}\text { Relaciona-se } \\
\text { parcialmente } \\
\text { (Entrevistado 4) } \\
\text { [...] a gente acaba usando as redes sociais, as ferramentas como o emaill, fazendo uma } \\
\text { pequena sintese do que acontece. E a gente também observa que dos próprios colegas, que } \\
\text { não existe muito interesse em saber o que acontece no conselho [...]" (Entrevistado 19) }\end{array}$ \\
\hline
\end{tabular}

Fonte: Dados da pesquisa.

Quanto ao relacionamento dos membros com seus grupos, conforme a Figura 12, as respostas ficaram divididas entre: aqueles que declaram que não se relacionam com seus grupos; aqueles que disseram, que dentro do possível, realizam esta interação; e outros que afirmaram que o seu relacionamento acontece, não como membro do CONSUNI, mas devido ao seu status na Universidade, cabendo, à sua representação, o encaminhamento e aprovação de políticas voltadas aos interesses públicos.

Scroferneker (2005) relata que a comunicação organizacional abrange todas as formas de comunicação utilizadas pela organização voltadas para os públicos ou segmentos com os quais se relaciona e depende. Segundo o entrevistado 1, "falta divulgar as ações da FURB ou se preocupar mais com essa prestação de serviços para a comunidade". Diante desta constatação, os meios, que os entrevistados julgam

Revista de Negócios, v. 23, n. 4, p. 7-24, October, 2018. 
adequados para a comunicação das ações da FURB quanto à responsabilidade social, foram: interna, mídia externa, presença na comunidade local e balanço social.

Figura 13 - Unidades de registro sobre comunicação.

\begin{tabular}{|c|c|}
\hline $\begin{array}{c}\text { Unidades de } \\
\text { registro }\end{array}$ & Relato na entrevista \\
\hline Interna & $\begin{array}{l}\text { "[...] eu penso que uma condição essencial é utilizar a TV FURB e a Rádio, que deveriam } \\
\text { ser melhor utilizados para isso.". (Entrevistado 5) } \\
\text { "No site a gente coloca informação, mas nem todos acessam. [...] Como o Interação, quem } \\
\text { sabe criar uma feira, um movimento para a empresas conhecerem, para a sociedade } \\
\text { conhecer a FURB [...] (Entrevistado 4) } \\
\text { "Eu vejo estudante da FURB entrando na página, para acessar o AVA, mas é um canal } \\
\text { que deveria ser melhor explorado." (Entrevistado 15) } \\
\text { "Tem a questão do endomarketing, nem entre nós a gente sabe o que está acontecendo." } \\
\text { (Entrevistado 21) }\end{array}$ \\
\hline Midia externa & $\begin{array}{l}\text { "O método mais tradicional é a imprensa. Hoje a televisão, nós temos a nossa televisão, } \\
\text { mas ela não tem audiência, é minima. [...] Tem que haver uma interação forte entre a } \\
\text { instituiçãa e os meios de divulgação, porque não adianta a universidade ter seu jornal, sua } \\
\text { televisão, tem que usar os meios que estão a alcance da comunidade." (Entrevistado 23) }\end{array}$ \\
\hline $\begin{array}{l}\text { Presença na } \\
\text { comunidade } \\
\text { local }\end{array}$ & $\begin{array}{l}\text { "Mas eu acredito que a FURB ela deveria, ao invés de produzir relatórios, ela se sentir } \\
\text { divulgada pela própria presença na comunidade. [...] A imagem que a FURB tem hoje, } \\
\text { infelizmente é de uma instituição elitista, restrita e com acesso a poucos." (Entrevistado } \\
\text { 14) }\end{array}$ \\
\hline Balanço social & 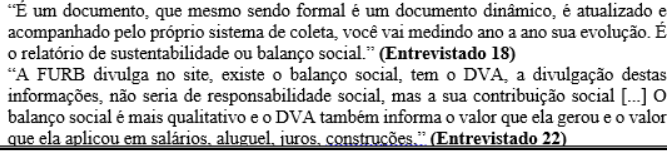 \\
\hline
\end{tabular}

Fonte: Dados da pesquisa.

Observa-se que os meios de comunicação oferecidos pela Instituição são vários: website institucional, TV Educativa, Rádio Educativa, redes sociais, entre outros (FURB, 2015), os quais, segundo os entrevistados poderiam ser explorados para aumentar a divulgação das ações de responsabilidade social. Além dos meios de comunicação institucionais, outras opções foram apontadas como: promoção de feiras e fóruns, nos quais a sociedade poderia participar, comunicação entre os servidores ou, como mencionado pelo entrevistado 21 na Figura 13, realizar endomarketing e a melhor utilização para divulgação do Ambiente Virtual de Aprendizagem (AVA).

Outra opção apontada para a comunicação das atividades, projetos ou programas de responsabilidade social realizados pela FURB foi a ampliação da comunicação por meio de veiculação em mídia externa, como televisão, rádio ou jornal impresso. Neste sentido, os entrevistados relataram que a abrangência da comunicação é maior, atingindo Blumenau e região, ou seja, pode atingir pessoas que não estão diretamente relacionadas com a FURB.

Para outros entrevistados, a melhor maneira de comunicação da FURB com a sociedade, é a elaboração de documentos institucionais específicos para a publicação de ações de responsabilidade social, cujos relatos foram agrupados na unidade de registro denominada balanço social.

Assim, a partir do estudo de caso analisado, compõem-se as seguintes proposições:

1. A Responsabilidade Social Universitária se desenvolve na universidade por meio do atendimento das demandas da sociedade.

2. As ações de Responsabilidade Social Universitária, segundo a percepção dos stakeholders, estão mais relacionadas a ações dos programas de extensão.

3. Os campos de Responsabilidade Social Universitária abarcam questões sociais, econômicas e ambientais.

4. A percepção dos stakeholders quanto a Responsabilidade Social Universitária está relacionado as ações de comunicação da universidade.

5. Os canais de relacionamento institucionais são responsáveis pela institucionalização de políticas e estratégias da RSU no âmbito do ensino, pesquisa, extensão e da getão.

6. Os modelos de gestão da universidade apresentam tanto impactos positivos, como negativos sobre a Responsabilidade Social Universitária.

\section{Conclusões}

Este estudo teve como objetivo analisar como os representantes dos grupos de interesse compreendem a responsabilidade social universitária da FURB. Para isso foi realizada pesquisa qualitativa, estudo de caso, na qual o objeto de estudo foi a Universidade Regional de Blumenau, Santa Catarina. A população deste estudo são os stakeholders primários e secundários da Instituição, cujos sujeitos escolhidos para responder à entrevista semiestruturada foram os membros do CONSUNI, com diferentes representatividades, entrevistando-se vinte e três membros, dos quarenta e três nomeados. Este grupo compõe um dos conselhos máximos da FURB, que tem a função deliberativa de atuação no que concerne à gestão universitária e, desta forma, tem poderes para atuar na responsabilidade social da universidade.

Os resultados apontaram que o entendimento sobre responsabilidade social dos entrevistados está de acordo com os conceitos apontados na literatura sobre o assunto, trazendo diversas

Revista de Negócios, v. 23, n. 4, p. 7-24, October, 2018. 
interpretações. Os representantes dos stakeholders têm uma visão ampliada sobre responsabilidade social universitária, supõe-se que esta amplitude pode estar influenciando na expectativa dos representantes quanto à atuação da Instituição.

No que tange aos impactos das atividades universitárias, percebe-se que o ensino foi identificado como a atividade principal da instituição, a pesquisa foi a atividade menos relacionada à responsabilidade social e a extensão a mais relacionada e também da qual alguns citaram programas/projetos. Isto demonstra que a percepção que as ações de responsabilidade social da Instituição estão voltadas para a atividade de extensão e que há fragilidade na integração entre as três atividades. Quanto à gestão foram avaliados os impactos quanto ao modelo de gestão adotado. A colegialidade está presente conforme preconiza a lei, contudo as demais formas de gestão apontada na literatura também impactam fortemente na gestão universitária. A colegialidade foi considerada adequada por todos os entrevistados, no entanto, alguns apontaram aspectos que apresentavam características do modelo político e anárquico, que impactavam negativamente na gestão. O modelo burocrático pode ser notado por meio da estrutura organizacional, dos estatutos e normas que regem a Instituição. Desta forma, destaca-se entre os impactos positivos: a preocupação com a formação cidadã; a diversidade de programas e convênios de extensão proporcionados à comunidade; e a gestão democrática. Os impactos negativos apontados são: a falta de articulação entre as atividades de ensino, pesquisa e extensão; a pouca visibilidade das atividades desenvolvidas; o tempo de resposta à comunidade quanto às decisões; e a falta de preparação dos membros para atuarem como conselheiros.

No tocante a relação da Furb com a sociedade, os resultados mostraram que a mesma surgiu de uma necessidade social e que teve papel fundamental para o desenvolvimento de Blumenau e região, tanto no aspecto social como econômico. No presente percebe-se que a FURB ainda desempenha papel importante para a sociedade, no entanto, outras instituições de ensino superior desempenham junto a ela a tarefa de qualificação profissional. Nota-se a expectativa de maior atuação na sociedade, mas conforme relatado pelos entrevistados, a instituição atua por meio dos diversos programas e projetos desenvolvidos.
Grande parte dos entrevistados relataram que a sua comunicação com os seus grupos de representados não acontece de forma satisfatória e também que esta comunicação pode estar fragilizada por não estar atingindo os stakeholders da FURB. Os canais para o relacionamento estão disponíveis para a instituição, porém falta institucionalizar políticas e estratégias que possibilitem que a Universidade seja percebida como cumpridora de suas responsabilidades sociais no âmbito do ensino, da pesquisa, da extensão e da gestão.

Assim, o presente estudo mostra a dificuldade de institucionalizar ações de responsabilidade social universitária, as quais são realizadas, mas estão fragmentadas e desarticuladas de forma a não propiciar condições para a indissociabilidade do ensino, da pesquisa e da extensão. Aspecto que reflete no relacionamento com os stakeholders, que muitas vezes não encontram os canais para especificar suas demandas, bem como conhecer o que é feito pela Instituição. Percebe-se que esta fragilidade não é exclusiva da FURB, como apontada pela literatura, mas ela pode estar influenciando na percepção da sua imagem pelos stakeholders, que a julgam como reativa e fechada.

Como contribuição teórica, estima-se que o presente trabalho possa contribuir para o entendimento do significado de responsabilidade social universitária, pois é considerado um tema abrangente e complexo. Com contribuição prática, espera-se que este diagnóstico permita à FURB conhecer seus pontos fortes e suas fragilidades, no que diz respeito à responsabilidade social e desta forma, contribuir para a melhoria dos processos de aferição de suas ações, como de relacionamento com a comunidade interna e externa.

Como limitação do método, destaca-se a dificuldade de inferir generalizações, uma vez que os resultados obtidos podem não se estender a outros casos. Além disso, as entrevistas foram realizadas com os membros do CONSUNI, composto por maioria stakeholders primários e internos, o que pode fazer prevalecer a percepção deste grupo específico.

\section{Referências}

Álvarez G. M. \& Liarte V. N. Responsabilidad social empresarial: de la visión de empresa e la visión de país. In: Licha, I. Enseñanza de la responsabilidad social empresarial: retos de las

Revista de Negócios, v. 23, n. 4, p. 7-24, October, 2018. 
universidades en Iberoamérica. Buenos Aires: Sudamericana, 2012.

Aprile, M. R., \& Barone, R. E. M. (2009). Educação superior: políticas públicas para inclusão social.Revista@mbienteeducação,2(1),39-55.

Ashley, P. A. (2002). Ética e responsabilidade social nos negócios. São Paulo: Saraiva.

Barbieri, José C. \& Cajazeira, J. E. R. (2009). Responsabilidade social empresarial e empresa sustentável: da teoria à prática. 2. ed. São Paulo: Saraiva.

Bardin, L. (2009). Análise de conteúdo. Lisboa: Edições 70.

Calderón, A. I. (2005). Responsabilidade social: desafios à gestão universitária. Revista Estudos, (34).

Calderón, A. I., Pedro, R. F., \& Vargas, M. C. (2011). Responsabilidade social da educação superior: a metamorfose do discurso da UNESCO em foco. Interface-Comunicação, Saúde, Educação, 15, 1185-1198.

Chauí, M. S. (2003). A universidade pública sob nova perspectiva. Revista Brasileira de Educação, n. 24 , p. 5-15, set./dez.

Cruvinel, E. (2008). Responsabilidade social em instituições financeiras: a institucionalização da prática nos bancos no Brasil. Elsevier.

Cunha, L. A. (2007). A universidade temporã: o ensino superior, da colônia à era de Vargas. 3. Ed. São Paulo: Editora UNESP.

Denzin, N. \& Lincoln, Y. (2006). O planejamento da pesquisa qualitativa: teorias e abordagens. Porto Alegre: Bookman.

Dias, R. (2012). Responsabilidade social: fundamentos e gestão. São Paulo: Atlas.

Durhan, E. (2005). A responsabilidade social das instituições de ensino superior. Estudos, v. 23, n.34, p. 59-62, abr.

Eisenhardt, K. M. (1989). Building theories from case study research. The Academy of Management
Review, v. 14, n. 4, p. 532-550.

Elkington, J. (1997). Cannibals with forks: the triple bottom line of 21 st century business. Capstone: Oxford.

Ellströn, P. (2007). Quatro faces das organizações educacionais. RBPAE, v.23, n.3, p. 49-461, set./dez.

Elpo, M. E. H. C. (2004). Avaliação da gestão universitária: velhos problemas e novas perspectivas. Anais do IV Colóquio Internacional sobre Gestão Universitária na América do Sul. Florianópolis.

Felicetti, V. L. (2011). Comprometimento do estudante: um elo entre aprendizagem e inclusão social na qualidade da educação superior. $298 \mathrm{f}$. Tese (Doutorado em Educação) - Pontifícia Universidade Católica do Rio Grande do Sul, Porto Alegre.

Furb, Fundação Universidade Regional de Blumenau. (2010). PDI 2010-1015. Blumenau.

Furlani, L. M. T. (2005). Responsabilidade social: o novo/velho desafio. Estudos, v. 23, n.34, p. 6372 , abr.

González, E. (2012). Perspectiva de los grupos de interés en la RSE. In: RAUFFLET, Emmanuel et al. Responsabilidad social empresarial. México: Pearson.

Gugel, M. A. (2004). Políticas públicas, ordem social, inclusão social. In: Seminário Internacional Sociedade Inclusiva: ações inclusivas de sucesso, 3., 2004, Belo Horizonte. Anais... Belo Horizonte: PUC Minas.

Guimarães, R. (2002). Pesquisa no Brasil: a reforma tardia. São Paulo em Perspectiva, n. 16, v.4, p. 41-47.

Hanashiro, D. M. M., Teixeira, M. L. M., \& Zaccarelli, L. M. (2007). Gestão do fator humano: uma visão baseada em stakeholders. São Paulo: Saraiva.

Herrera M. A. (2012). Enfoques académicos em enseñanza-investigación en responsabilid social empresarial. In: Licha, I. Enseñanza de la

Revista de Negócios, v. 23, n. 4, p. 7-24, October, 2018. 
responsabilidad social empresarial: retos de las universidades en Iberoamérica. Buenos Aires: Sudamericana.

INEP, Instituto Nacional de Estudos e Pesquisas Educacionais Anísio Teixeira. (2004). SINAES. Disponível em: http://portal.inep.gov.br/superiorsinaes. Acesso em: 10 mar. 2015.

Jamali, D. (2008). A stakeholder approach to corporate social responsibility: A fresh perspective into theory and practice. Journal of business ethics, 82(1), 213-231.

Jimenez, M., Fontecilla, J. M. F. \& Troncoso, C. D. (2006). Responsabilidade universitária: uma experiência inovadora na América Latina. Estudos, Brasília-DF, ano, 24, 57-73.

Jugón, M. \& Corral, S. (2012). Actividades optativas e integradas a la oferta curricular, responsabilidad social empresarial y responsabilidad social universitaria. In: Licha, I. Enseñanza de la responsabilidad social empresarial: retos de las universidades en Iberoamérica. Buenos Aires: Sudamericana.

Junqueira R., \& Kyoko Wada, E. (2011). Stakeholders: estratégia organizacional e relacionamento. Estudo de casos múltiplos do setor hoteleiro. Revista Ibero Americana de Estratégia, 10(3).

Kotler, P. (2013). Administração de marketing. 14. ed. São Paulo: Pearson.

Macedo, A. R. (2005). O papel social da universidade. Estudos, v. 23, n.34, p. 7-12, abr.

Machado, N. S. \& Silveira, A. (2008). Configurações estruturais em organizações universitárias. Florianópolis: Insular.

Machado, N. S. \& Silveira, A. (2008). Configurações estruturais em organizações universitárias. Florianópolis: Insular.

Maciel, A. L. S., Kowalski, A. V. \& Menezes, V. F. (2009). A responsabilidade social das instituições de ensino superior: um estudo a partir das práticas em desenvolvimento no Rio Grande do Sul. 2009. In: Colóquio Internacional Gestão
Universitária na América do Sul, Florianópolis. Anais... Florianópolis.

Macke, J., \& Carrion, R. D. S. M. (2006). Planejamento, implementação e avaliação de programas sociais: uma proposta de inovação. REAd: revista eletrônica de administração. Porto Alegre. Edição 53, vol. 12, $n$. 5 (set./out. 2006), documento eletrônico.

Mainardes, E. W., Alves, H., Raposo, M., \& Domingues, M. J. C. S. (2011). Um novo modelo de classificação de stakeholders. Anais do Encontro de Estudos em Estratégia (3Es), Porto Alegre, RS, Brasil, 5.

Marchiori, M. (2010). Os desafios da comunicação interna nas organizações. Conexão, v. 9, n. 17, jan./jun.

Martino, S. (2012). Formación ética transversal en la currícula universitaria: emprendimos el camino. In: LICHA, Isabel. Enseñanza de la responsabilidad social empresarial: retos de las universidades en Iberoamérica. Buenos Aires: Sudamericana.

Mascarenhas, M. P., \& Silva, W. A. C. (2013). Triple bottom line da sustentabilidade uma análise em empresas nacionais produtoras de óleos e gorduras vegetais e animais. REVISTA REUNIR, 3(1), 62-79.

Medeiros Jr. G. J. (2004). Universidade e Responsabilidade Social. 2004. In: anais IV Colóquio Internacional Gestão Universitária na América do Sul, 2004, Florianópolis. Anais... Florianópolis.

Melo Neto, F. P. (2001). Responsabilidade social \& cidadania empresarial: a administração do terceiro setor. Qualitymark, Rio de Janeiro.

Meyer Jr, V. (2007). A escola como organização complexa. In: Eyng, A. M. \& Gisi, M. L. Políticas e gestão da educação superior. Editora UNIJUI, Ijui.

Morais, N., Almeida, L. S., \& Montenegro, M. I. (2006). Percepções do ensino pelos alunos: uma proposta de instrumento para o ensino superior. Análise Psicológica, 24(1), 73-86. 
Oliveira, J. A. P. (2008). Empresas na sociedade: sustentabilidade e responsabilidade social. Rio de Janeiro: Elsevier.

Paro, V. H. (2007). Gestão escolar, democracia e qualidade do ensino. São Paulo: Ática.

Paula, S. L., \& Mendonça, J. R. (2014). A construção de uma impressão socialmente responsável: um estudo em Instituições de Ensino Superior a partir da Comunicação Organizacional. Revista de Negócios, 19(1), 44-69.

Pereira, M. F., Melo, P. A., \& Cunha, M. S. (2008). A História e a experiência da Universidade Federal de Santa Catarina com o Processo de Planejamento Estratégico. Domingues, M.J.C.S. \& Silveira, A. Gestão de Ensino Superior: temas contemporâneos. Blumenau: Edifurb, 127-150.

Pinheiro, H D. (2011). Redesenho das configurações estruturais na gestão universitária: ações derivadas da inovação e flexibilidade na legislação pós-LDB 1996. 2011. 359f. Tese (Doutorado em Administração) - Universidade Federal do Rio Grande do Norte, Natal.

Pinto, M. M. (2012). Responsabilidade social universitária: o caso da Universidade de Santa Cruz do Sul. Santa Cruz do Sul: EDUNISC.

Piñol, S. T. (2004). A imagem das instituições de ensino superior junto às empresas de seleção e recrutamento. Gestão Universitária. Florianópolis: Insular.

Ribeiro, R. M. D. C. (2013). Responsabilidade social universitária e a formação cidadã. 163f. Tese (Doutorado em Educação) - Pontifícia Universidade Católica do Rio Grande do Sul, Porto Alegre

Rizzatti, G. \& Dobes, C. E. I. (2004). A complexidade do processo decisório em universidades. In: Melo, P. A.; Colossi, N. Cenários da gestão universitária na contemporaneidade. Florianópolis: Insular.

Rösler, M. R.\& Ortigara, C. J. (2005). Qualidade na educação e desafios da globalização. Estudos, v. 23 , n. 34 , abr.

Rossetto, M. R. C. A. \& Brito, R. L. G. L. (2013).
Responsabilidade social das instituições do ensino superior: o discurso das lideranças do setor educacional brasileiro. In: Horta, C. E. R. \& Lima, L. L. Responsabilidade social. Brasília: ABMES Edutora.

Santos, B. D. S. (2004). A universidade no século XXI: para uma reforma democrática e emancipatória da universidade. Cortez: São Paulo.

Schiavi, M. V. (2012). Responsabilidad social empresarial, consumo sustentable y consumidor. In: LICHA, Isabel. Enseñanza de la responsabilidad social empresarial: retos de las universidades en Iberoamérica. Buenos Aires: Sudamericana.

Schwartzman, J. (2005). Responsabilidade social no ensino superior. Estudos, v. 23, n.34, p. 47-54, abr.

Scroferneker, C. M. A. (2015). Perspectivas teóricas da comunicação organizacional. 2005. Disponível em: <http://www.eca.usp.br/alaic/boletin11/cleusa.htm $>$. Acesso em: 22 jun. 2015.

Silva, C. M. (1991). Modelos burocrático e político de estrutura organizacional de universidades. In: Temas de administração universitária. Florianópolis/CPGA.

Silva, I. A. D. (2014). Educação socialmente responsável: expressões no ensino de graduação em universidade comunitária. 272f. Tese (Doutorado em Educação) - Pontifícia Universidade Católica do Rio Grande do Sul, Porto Alegre.

Sobrinho, J. D. (2014). Gestão universitária: contradições entre privado e público. Revista Forges, v. 1, n. 1, p. 67-87.

Souza, P. N. P. (1997). LDB e ensino superior: estrutura e funcionamento. São Paulo: Pioneira.

Stake, R. E. (1995). The art of case study research. London: Sage Publications.

Vallaeys, F. (2006). O que significa responsabilidade social universitária. Revista Estudos, 24(36).

Revista de Negócios, v. 23, n. 4, p. 7-24, October, 2018. 
Vallaeys, F. (2008). " Responsabilidad Social Universitaria": una nueva filosofía de gestión ética e intenigentes para las universidades. Revista Educación Superior y Sociedad (ESS), 13(2), 191220.

Vallaeys, F.; (2009). CRUZ, Cristina de la; SASIA, Pedro M. Responsabilidad social universitaria: manual de primeros pasos. México: McGraw-Hill Interamericana.

Vallaeys, F. (2012). Campus responsable. In: Jaramillo G., María A.; Zuluaga, Bárbara G. Responsabilidad social universitaria: autoevaluación del sistema universitario de extensión. Medellín: Universidad de Antioquia.

Vallaeys, F. (2014). La responsabilidad social universitaria: un nuevo modelo universitario contra la mercantilización. Revista iberoamericana de educación superior, 5(12), 105-117.

Vergara, S. C. (2013). Projetos e relatórios de pesquisa em administração. 14. ed. São Paulo: Atlas.

Villarreal, L. Y. (2014). Responsabilidad Social Universitaria: un reto de las instituciones de educación superior. Daena: International Journal of Good Conscience, v. 9, n. 1, p. 158-187, mar.

Yin, R. K. (2009). Estudo de caso: planejamento e métodos. 4. ed. Porto Alegre: Bookmann. 